\title{
Efficacy of early postoperative radiotherapy for nonfunctioning null cell or silent pituitary macroadenomas
}

Cristina Stancu ${ }^{1}$, Anca Campean ${ }^{2}$, Monica Gheorghiu ${ }^{1,3}$, Simona Galoiu ${ }^{1,3}$, Rodica Anghel ${ }^{4}$, Corin Badiu ${ }^{1,3}$, Marius Raica ${ }^{2}$, Mihail Coculescu ${ }^{1,3}$

\author{
1Endocrinology Department, "Carol Davila" University of Medicine and Pharmacy, Bucharest, 2"Victor Babes" University of Medicine and

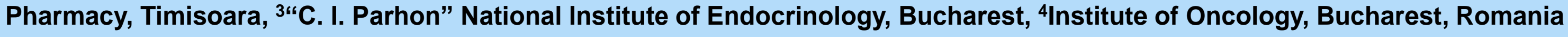

\section{INTRODUCTION}

The high voltage radiotherapy (RT) after surgery for nonfunctioning pituitary macro adenomas (NFMAs) is still controversial, subjected to rapid technical and medical progress.

\section{AIM}

To appreciate the best period of time for RT in patients with pituitary macro adenomas with residual tumor after surgery.

\section{SUBJECTS AND METHODS}

We studied 97 patients with residual NFMAs to identify factors affecting tumor control such as the time of RT and tumor immunopathology. Partial pituitary surgery was performed either by trans frontal (35 patients) or transsphenoidal (62 patients) approach. High voltage RT (mean total dose 50.5 Gy) was given to $41 / 97$ patients. Twenty out of 41 patients had RT within the first year after surgery (Group A) and 21/41 had RT after 1year (Group B). Fifty six out of 97 patients with surgery, without RT, represent the control group (Group C) (Fig.1). The increase of the postoperative remnant was defined as a minimum $25 \%$ increase of any diameter (either transversal or vertical) by serial imaging studies. The immunoperoxidase analysis (avidin biotine technique) for the anterior pituitary hormones and the final immunopathological classification of the NFMAs revealed: 44 null cell adenomas (a) (immunostainig was negative for all hormones), 23 gonadotropinomas (b) (positive immunostainig for $\mathrm{LH} \beta$ and $\mathrm{FSH} \beta$ ) and 30 plurihormonal (immunostainig positive for more pituitary hormones different from gonadotropins) or unihormonal silent adenomas (c) (immunostaining positive for ACTH, GH or PRL), (Table1).

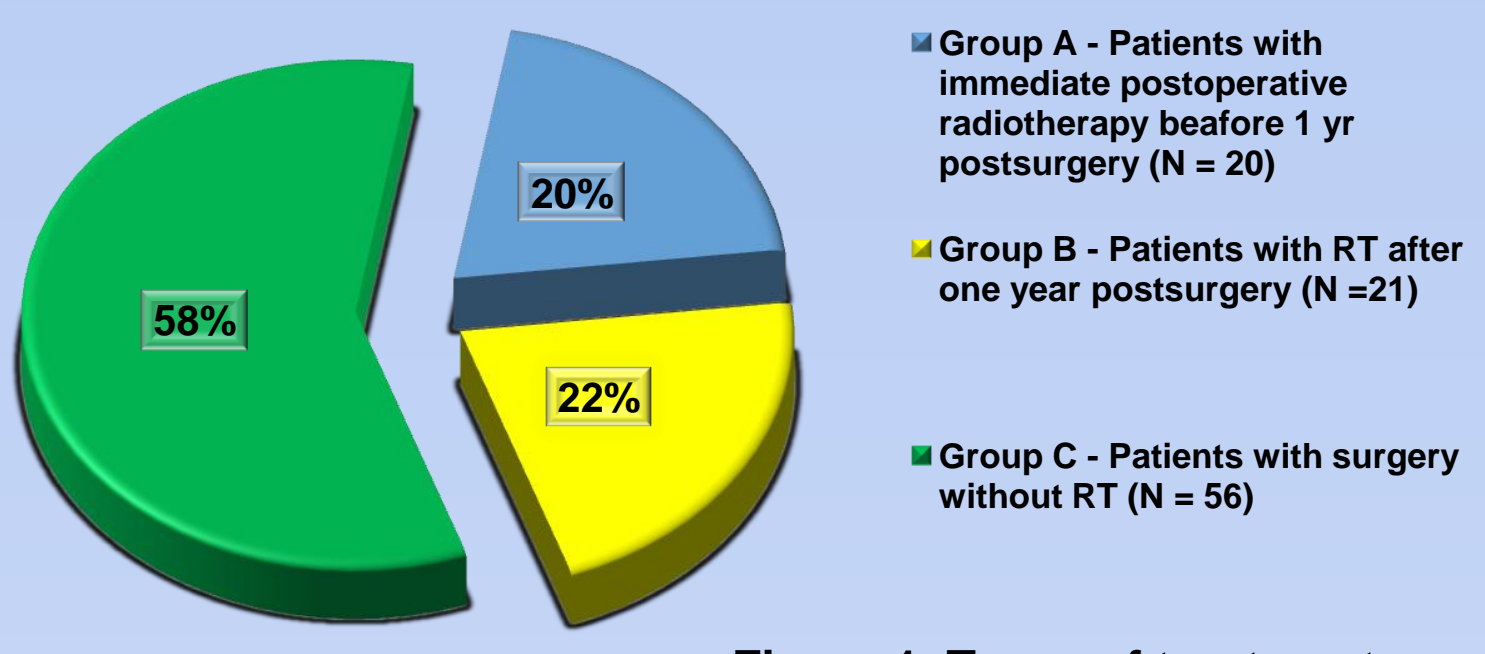

Figure 1. Types of treatment.

Table 1. General characteristics of patients

\begin{tabular}{|c|c|c|c|}
\hline & \multicolumn{2}{|c|}{$\begin{array}{l}\text { Patients with radiotherapy after } \\
\text { surgery }(\mathrm{N}=41)\end{array}$} & \multirow{2}{*}{$\begin{array}{l}\text { Control Group } \\
\text { Group C (N = 56) } \\
\text { Patients after } \\
\text { surgery, without RT }\end{array}$} \\
\hline & $\begin{array}{l}\text { Group A (N = } \\
20 \text { ) } \\
\text { RT up to } 1 \mathrm{yr}\end{array}$ & $\begin{array}{l}\text { Group } B(N=21) \\
\text { RT after } 1 \mathrm{yr}\end{array}$ & \\
\hline $\begin{array}{l}\text { Mean age of } \\
\text { diagnostic (yrs) }\end{array}$ & $44.5 \pm 11.64$ & $47 \pm 11.62$ & $50 \pm 12.92$ \\
\hline Sex ratio $(M / F) n$ & $10 / 10$ & $18 / 3$ & $28 / 28$ \\
\hline $\begin{array}{l}\text { Mean size }(\text { range }) \\
\text { postoperative } \\
\text { remnant }(\mathrm{cm})\end{array}$ & $\begin{array}{l}2.72(0.90- \\
4.70)^{\star}\end{array}$ & $1.94(0.66-4.50)^{\star}$ & $1.63(0.50-5.50)^{\star}$ \\
\hline $\begin{array}{l}\text { Patients with } \\
\text { remnant grater } 2 \\
\text { cm in size }(n, \%) \\
\end{array}$ & $15 / 20(75 \%)^{*}$ & $10 / 21(48 \%)$ & $17 / 56(30 \%)^{*}$ \\
\hline $\begin{array}{l}\text { Patients with supra } \\
\text { sellar remnant }(n, \%)\end{array}$ & $15 / 20(75 \%)^{*}$ & $14 / 21(67 \%)^{*}$ & $21 / 56(37 \%)^{*}$ \\
\hline $\begin{array}{l}\text { Mean (range) time } \\
\text { of RT after surgery } \\
\text { (mo) }\end{array}$ & $6(2-12)$ & 24 (14-89) & - \\
\hline $\begin{array}{l}\text { Cavernous sinus } \\
\text { invasion }(n, \%)\end{array}$ & $13 / 20(65 \%)^{*}$ & $7 / 21(33 \%)$ & $21 / 56(37 \%)^{*}$ \\
\hline Visual field deficits & $14 / 20(70 \%)$ & 18/21 (86\%) & $41 / 56$ (73\%) \\
\hline IHC $\mathbf{a} / \mathbf{b} / \mathbf{c}$ & $7 / 3 / 10$ & $12 / 4 / 5$ & $25 / 16 / 15$ \\
\hline
\end{tabular}

${ }^{*} \mathrm{p}<0.05$, Group A vs Group C and Group B vs Group C

\section{RESULTS}

Table 2. The rate of the residual tumor regrowth in relation to the high voltage radiotherapy (RT)

\begin{tabular}{|c|c|c|c|c|c|c|c|c|}
\hline \multicolumn{2}{|c|}{$\begin{array}{l}\text { Total number of } \\
\text { patients } \\
(n=97)\end{array}$} & \multicolumn{3}{|c|}{$\begin{array}{l}\text { No. of patients with } \\
\text { regrowth at } 5 \text { years } \\
\text { according to } \\
\text { postoperative } R T\end{array}$} & \multicolumn{2}{|c|}{$\begin{array}{l}\text { No. of regrowth } \\
\text { after surgery } \\
\text { without RT } \\
\text { according to } \\
\text { immunohistoch } \\
\text { emistry }\end{array}$} & \multicolumn{2}{|c|}{$\begin{array}{l}\text { No. of regrowth } \\
\text { after } \mathrm{RT} \\
\text { according to } \\
\text { immunohistoch } \\
\text { emistry }\end{array}$} \\
\hline $\begin{array}{l}\text { Null cell } \\
\text { adenoma }\end{array}$ & $\begin{array}{l}\text { Silent } \\
\text { hormone } \\
\text { adenoma }\end{array}$ & $\begin{array}{l}\text { RT + } \\
(<1 y r)\end{array}$ & $\begin{array}{l}\mathrm{RT}+ \\
(>1 \mathrm{yr})\end{array}$ & No $R T$ & $\begin{array}{l}\text { Null } \\
\text { cell }\end{array}$ & $\begin{array}{l}\text { Silent } \\
\text { hormone }\end{array}$ & \begin{tabular}{|l|} 
Null \\
cell
\end{tabular} & \begin{tabular}{|l} 
Silent \\
hormone
\end{tabular} \\
\hline $\begin{array}{l}44 \\
(45 \%)\end{array}$ & $\begin{array}{l}53 \\
(55 \%)\end{array}$ & $\begin{array}{l}2 \\
(2 \%)\end{array}$ & $\begin{array}{l}5 \\
(2 \%)\end{array}$ & $\begin{array}{l}22 \text { * } \\
(39 \%)\end{array}$ & $\begin{array}{l}7 \\
(16 \%)\end{array}$ & $\begin{array}{l}15 \text { * } \\
(28 \%)\end{array}$ & \begin{tabular}{|l}
4 \\
$(9 \%)$
\end{tabular} & \begin{tabular}{|l}
3 \\
$(6 \%)$
\end{tabular} \\
\hline
\end{tabular}

Patients without RT (control group $\mathrm{C}$ ) have a significant higher regrowth rate of residual tumor versus patients with RT ( $p=0.025)$, at 5 years. Only $2 / 20$ patients with immediate RT (group A) have regrowth at 5 years and $5 / 21$ patients from group $B$, see Table 2, Fig.2. The chance for the remnant regrowth is decreased in group $A$ vs group $B(O R=0.35)$.

It is important to emphasize that patients from group $A$ vs patients from group control, without RT, have had more tumors with cavernous sinus invasion ( $p=0.038)$, with high postoperative remnant $(p=0.001)$ or with size more than $2 \mathrm{~cm}(\mathrm{p}=0.001)$ and with residual mass outside the sella $(p=0.003)$. Patients from group B vs control, group $C$, showed also statistically significant higher postoperative remnant $(p=0.047)$ and residual mass with suprasellar extension ( $p=0.023$ ), (Table 1).

Figure 2. The regrowth up to 5 years of the postoperative remnant of the null cell and silent uni/plurihormone pituitary macro adenomas

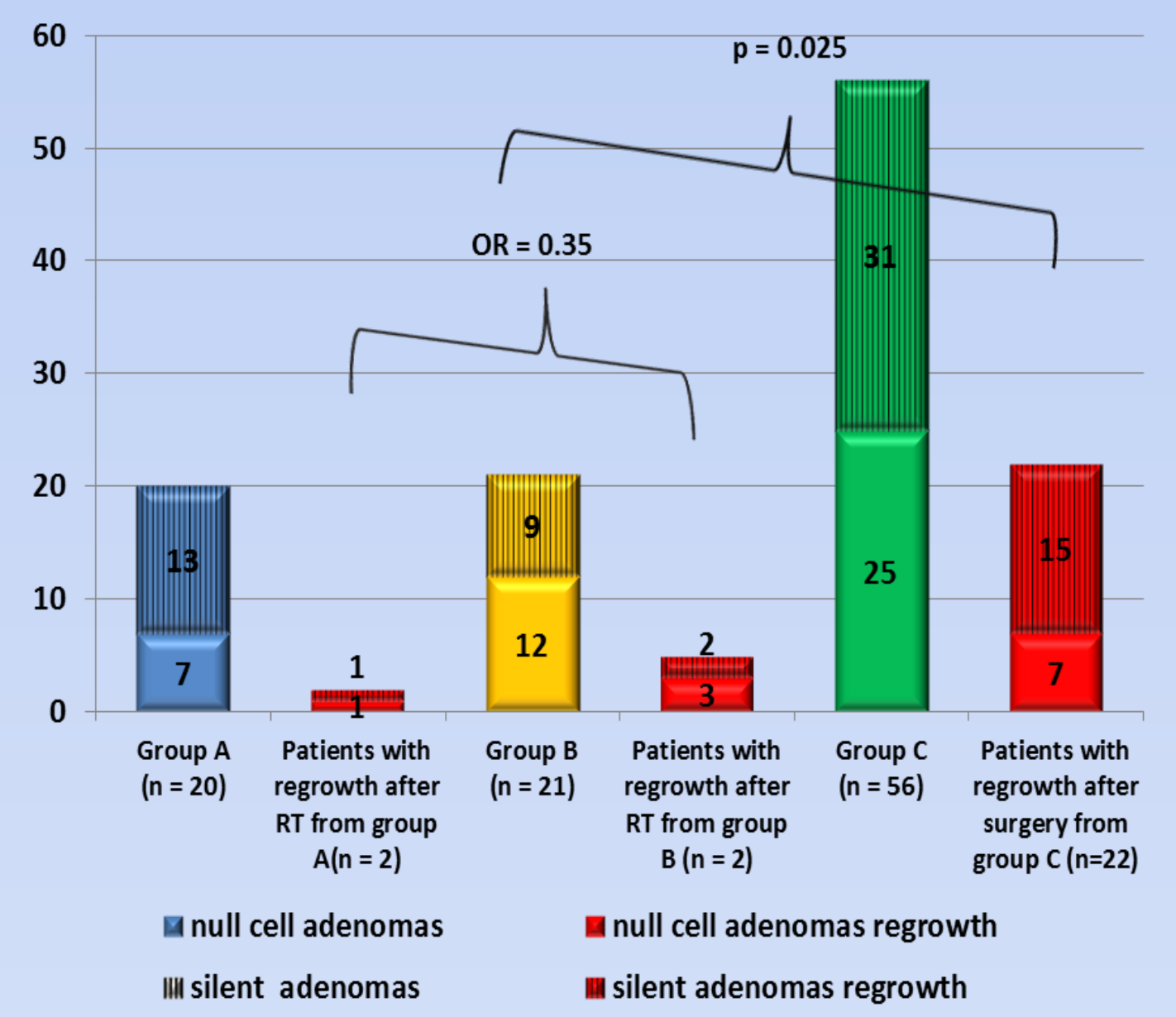

In the control group $\mathrm{C}$, without $\mathrm{RT}$, the patients with silent hormone adenomas have a regrowth rate more frequently than patients with null cell adenomas ( $\mathrm{p}=0.060, \mathrm{Cl} 90 \%$ ), (Table 2 ).

In the groups $A$ and $B$, we observed by contrast that postoperative RT is associated with lower risk of residual tumor regrowth for these type of tumors expressing hormones vs null cell adenomas $(\mathrm{OR}=0.16)$ (Fig 2).

\section{CONCLUSIONS}

It is tempting to suggest as an optimal time for radiotherapy is the first year post partial surgery of nonfunctioning pituitary macro adenomas. Special attention should be given for uni/plurihormonal silent adenomas (as shown by immunohistochemistry). 